\title{
PERFORMANCE OF WHEAT VARIETIES UNDER LATE PLANTING- INDUCED HEAT STRESS CONDITION
}

\author{
M. M. Rahman'1, M. A. Hasan' ${ }^{2}$ M. F. Chowdhury ${ }^{2}$, M. R. Islam ${ }^{1}$ and M. S. Rana ${ }^{1 *}$ \\ ${ }^{1}$ Department of Crop Physiology \& Ecology, Hajee Mohammad Danesh Sci. \& Technology University, Dinajpur \\ ${ }^{2}$ Department of Agronomy and Agricultural Extension, Rajshahi University \\ ${ }^{*}$ Corresponding author, E-mail: sohe10901084@gmail.com
}

(Received: 8 May 2017, Accepted: 23 April 2018)

Keywords: Wheat genotypes, late planting, heat stress tolerance and yield

\begin{abstract}
The effect of late planting heat stress on physiological traits, yield attributes and yield of four wheat varieties (BARI Gom 25, BARI Gom 26, BARI Gom 28 and Sourav) were tested in the study. November 30 sowing was considered as control and December 30 sowing as the late planting heat stress condition. Wheat Var. BARI Gom 25, BARI Gom 26 and BARI Gom 28 showed greater stability of flag leaf chl, higher level of proline in flag leaf and kernel and greater ability to keep the canopy cooler compared to Sourav under late planting heat stress condition. More spike dry matter accumulation at peak, longer grain growth duration, better yield components such as number of grains spike ${ }^{-1}$, grain weight spike ${ }^{-1}$ and 1000 -grain weight under heat stress contributed to better tolerance of BARI Gom 25, BARI Gom 26 and BARI Gom 28. The order of tolerance based on grain yield was BARI Gom $25>$ BARI Gom $28>$ BARI Gom $26>$ Sourav and the order of tolerance based on above ground biological yield was BARI Gom 28 > BARI Gom $26>$ BARI Gom $25>$ Sourav.
\end{abstract}

\section{Introduction}

Wheat (Triticum aestivum L.) is the world's most widely cultivated food crop. It is the second important cereal crop after rice, and grown worldwide as the major sources of energy for human being. Bangladesh covers an area of 0.43 million hectare for wheat cultivation with an annual production of about 1.30 million metric tons and average grain yield of $3.03 \mathrm{t} \mathrm{ha}^{-1}$ (Anonymous, 2014). In Bangladesh, about $60 \%$ of the wheat is cultivated at late sowing condition after harvesting the transplanted aman rice (Badaruddin et al., 1994).

Late planting wheat exposed to high temperature (mean air temperature of $>26^{\circ} \mathrm{C}$ ) at reproductive stage causing reduction in yield and it is one of the major reasons of yield gap (Hasan and Ahmed, 2005). However, this problem will be further increased due to global warming. In this context, the temperature in Bangladesh would be increased to $1.3^{\circ} \mathrm{C}$ and $2.6^{\circ} \mathrm{C}$ by the year 2030 and 2075, respectively with respect to the base year 1990. In spite of low yield of wheat due to post anthesis heat stress, cultivation of wheat cannot be avoided totally. Because the irrigation dependent Boro rice cultivation may need to be replaced in future by partially irrigated or non irrigated wheat cultivation. Therefore, effort ought to be made to minimize the late sown yield reduction by screening or developing high temperature tolerant wheat genotypes/varieties or by ameliorating the effect of heat stress through agronomic strategies.

Different yield related characters were identified as contributing to heat tolerance in wheat. The most responsive yield component are number of grain $\operatorname{spike}^{-1}$, grains spikelet ${ }^{-1}$, grain weight, rate of grain filling, biomass at harvest (Zong-hu and Rajaram, 1994). In addition to these, other 
physiological characters like chlorophyll (chl) content, stem reserves mobilization (Sikder and Paul, 2010), canopy temperature depression (Sikder and Paul, 2010) and stomata conductance (Renolds et al., 1994) have been associated with performance of wheat under high temperature level. Considering the above importance the present investigation was carried out to study the sensitivity of physiological traits resulting reduced grain yield of wheat in heat stressed environment and to observe the effect of late planting heat stress on yield contributing characters and yield of wheat.

\section{Materials and Methods}

The experiment was set up at the research farm of Crop Physiology and Ecology Department, Hajee Mohammad Danesh Science and Technology University, Dinajpur, Bangladesh. The experiment was conducted in a split- plot design with three replications. The unit plot size was $2.5 \mathrm{~m}$. x $2.4 \mathrm{~m}$. November 30 sowing was considered as control and December 30 sowing as late planting heat stress condition. Sowing times were placed in the main plots whereas four wheat varieties viz., BARI Gom 25, BARI Gom 26, BARI Gom 28 and Sourav in the sub-plots. A fertilizer dose of 140-35-75-18-2-0.5 $\mathrm{kg} \mathrm{ha}^{-1} \mathrm{~N}, \mathrm{P}, \mathrm{K}, \mathrm{S}, \mathrm{Zn}$ and B was applied in the form of urea, triple super phosphate (TSP), muriate of potash (MOP), gypsum and boric acid, respectively. After land preparation, full dose of $\mathrm{P}, \mathrm{K}, \mathrm{S}, \mathrm{Zn}, \mathrm{B}$ and two-third of $\mathrm{N}$ were incorporated thoroughly into the soil as basal dose. The remaining amount of $\mathrm{N}$ was applied at 25 after seedlings emergence. Seeds of four wheat varieties were sown on November 30, 2014 and December 30, 2014 in rows of $20 \mathrm{~cm}$ apart, at the rate of $120 \mathrm{~kg} \mathrm{ha}^{-1}$. After sowing, light irrigation was given for uniform germination and other intercultural operations were done as per requirement. Maximum, minimum and mean air temperature was recorded and days required to anthesis also calculated.

\section{Spike dry matter accumulation}

At anthesis 80 main shoots were tagged from each plot. Four tagged main shoot spikes were harvested at every $4^{\text {th }}$ day beginning from anthesis to quantify spike dry matter accumulation pattern. Collection of main shoot spike in all genotypes was continued up to 40 days after anthesis (DAA) for both well watered and water deficit stress condition. The harvested spikes were kept in oven at $70^{\circ} \mathrm{C}$ for 72 hours. After oven drying, spikes were weighted with an analytical balance (AND Electronic Balance Model EK 300 i).

\section{Determination of free proline content}

Proline (Pro) content of flag leaf and kernel at 16 DAA of wheat genotypes grown in two growing conditions were estimated according to Bates (1973) from a standard curve and calculated on a fresh weight basis as follows:

$\mu$ moles Pro $\mathrm{g}^{-1}$ of fresh plant material $=$

$\{(\mu \mathrm{g}$ Pro / $\mathrm{ml} \mathrm{x} \mathrm{ml} \mathrm{toluene}) / 115.5 \mu \mathrm{g} / \mu$ moles $\} /$ (g sample/5)

\section{Determination of chlorophyll content}

Total chl content of the flag leaf at 8 and 24 days after anthesis was estimated according to Witham et al. (1986) using following formula-

Total chl $\left(\mathrm{mg} \mathrm{g}^{-1} \mathrm{FW}\right)=\left[20.2\left(\mathrm{D}_{645}\right)+8.02\left(\mathrm{D}_{663}\right)\right] \times[\mathrm{V} /(1000 \mathrm{x} \mathrm{W})]$

(Where, $\mathrm{V}=$ Volume of $80 \%$ aqueous acetone $(\mathrm{ml}), \mathrm{W}=$ Weight of fresh leaf $(\mathrm{g})$, $\mathrm{D}_{645}=$ Absorbance at $645 \mathrm{~nm}$ wave length and $\mathrm{D}_{663}=$ Absorbance at $663 \mathrm{~nm}$ wavelength)

\section{Determination of leaf relative water content (RWC)}


Relative water content in flag leaf was determined at 16 DAA from the equation of Schonfeld $e t$ al. (1988).

RWC $(\%)=\{($ Fresh weight - Dry weight $) /($ Turgid weight - Dry weight $)\} \times 100$

\section{Canopy temperature Depression (CTD)}

The hand held infra-red thermometer (Model: Crop TRACK item no. 2955L-Spectrum Tecnologies, Inc.) was used to measure the CTD at 8 and 24 DAA during noon period under bright sunlight and less wind conditions.

\section{Agronomical traits}

Plant height, spike length (excluding awn), number of spikes $\mathrm{m}^{-2}$, number of grains spike ${ }^{-1}$, grain dry weight spike ${ }^{-1}$, thousand grain weights, grain yield and above ground biological yield of wheat genotypes were taken properly. Grain and above ground biological yield were adjusted to $12 \%$ moisture content.

\section{Stress susceptibility index (SSI)}

Stress susceptibility index (SSI) was calculated for grain yield using following formula $\mathrm{SSI}=\left(1-\mathrm{Y} / \mathrm{Y}_{\mathrm{p}}\right) /\left(1-\mathrm{X} / \mathrm{X}_{\mathrm{p}}\right)$

(Where, $\mathrm{Y}=$ Grain yield of genotype in a stress environment, $\mathrm{Y}_{\mathrm{p}}=$ Grain yield of genotype in a stress-free environment, $X=$ Mean $Y$ of all genotypes and $X_{p}=$ Mean $Y_{p}$ of all genotypes

All the collected data were analyzed by partitioning the total variance with the help of computer by using MSTAT program. The treatment means were compared using Duncun's Multiple Range Test (DMRT) at $\mathrm{P} \leq 5 \%$ level. Correlation analysis was done using MSTAT program.

\section{Result and Discussion}

\section{Maximum, minimum and mean air temperature during the growing period}

Maximum, minimum and mean air temperature recorded from the experimental site during 16 January to 16 April 2015 is presented in Fig. 1. From this figure it is revealed that the wheat varieties sown on November 30 experienced less than $26^{\circ} \mathrm{C}$ throughout their whole reproductive growth phase was considered as control and wheat varieties sown on December 30 experienced more than $26^{\circ} \mathrm{C}$ considered as late planting heat stress. 


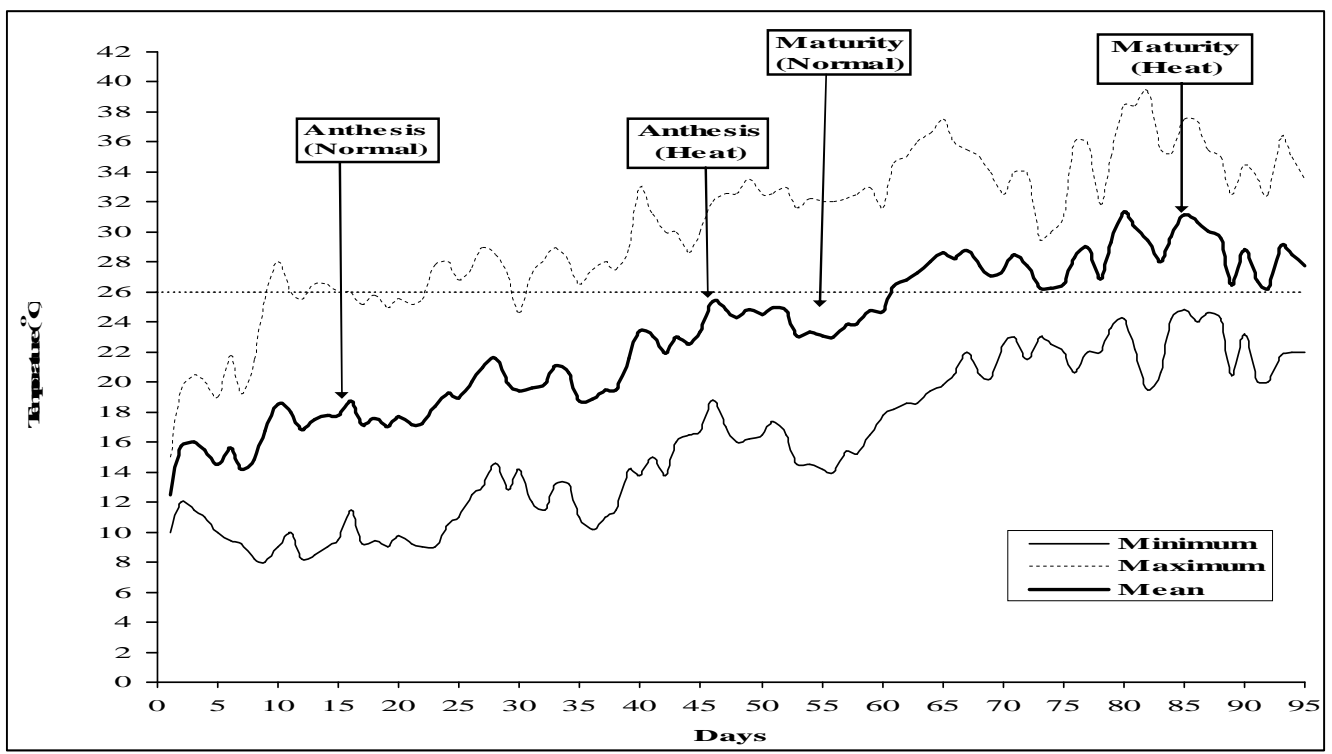

Fig. 1. Maximum, minimum and mean air temperature from 16 January to 16 April 2015 showing the period of anthesis and maturity of normal and late planting wheat.

\section{Phenological parameters}

Due to late planting heat stress number of days required to anthesis was reduced but it was not influenced significantly by the interaction effect of wheat varieties and temperature regimes (Table 1). Under late planting heat stress condition, all the wheat varieties required shorter time (63-64 days) to attain anthesis compared to control (73-74 days).

Table 1. Effect of late planting heat stress on days required to attain anthesis and physiological maturity of different wheat varieties

\begin{tabular}{llcccc}
\hline Wheat varieties & $\begin{array}{l}\text { Temperature } \\
\text { regimes }\end{array}$ & \multicolumn{2}{c}{ Days to anthesis } & \multicolumn{2}{c}{$\begin{array}{c}\text { Days to physiological } \\
\text { maturity }\end{array}$} \\
\cline { 3 - 6 } & & $\begin{array}{c}\text { Number } \\
\text { of days }\end{array}$ & $\begin{array}{c}\text { Early in days } \\
\text { over control }\end{array}$ & $\begin{array}{c}\text { Number } \\
\text { of days }\end{array}$ & $\begin{array}{c}\text { Early in days } \\
\text { over control }\end{array}$ \\
\hline BARI Gom 25 & Control & 73 & - & $113 \mathrm{a}$ & - \\
& Heat stress & 64 & 9 & $104 \mathrm{a}$ & 7 \\
BARI Gom 26 & Control & 73 & - & $113 \mathrm{a}$ & - \\
& Heat stress & 63 & 9 & $95 \mathrm{~b}$ & 18 \\
BARI Gom 28 & Control & 73 & - & $109 \mathrm{a}$ & - \\
& Heat stress & 63 & 10 & $95 \mathrm{~b}$ & 14 \\
\multirow{2}{*}{ Sourav } & Control & 74 & - & $114 \mathrm{a}$ & - \\
& Heat stress & 63 & 11 & $91 \mathrm{c}$ & 23 \\
\hline \multirow{2}{*}{ Level of significance } & NS & & $*$ & \\
CV $(\%)$ & 1.42 & & 3.50 & \\
\hline
\end{tabular}

In a column, values followed by similar letter (s) did not differ significantly by DMRT at P $\leq 5 \%$. Asterisk represents level of significance.

Wheat varieties and temperature regimes interacted significantly to influence the number of days required to attain physiological maturity (Table 1). Under late planting heat stress condition, all the wheat varieties required shorter time (91-104 days) to attain physiological 
maturity compared to control (109-114 days). Sourav required maximum days (114 days) to attain physiological maturity under control and it attained at physiological maturity 23 days earlier under heat stress condition, BARI Gom 25 required 113 days to and 7 days earlier under heat stress condition, BARI Gom 26 required 113 days under control and 18 days earlier under heat stress condition whereas BARI Gom 28 required minimum days (109 days) under control and 14 days earlier under heat stress condition. The Phonological stages of wheat were influenced by the environment during growing period. Sikder (2009) observed that the number of days for attaining anthesis, grain filling and maturity stages were higher for normal sowing condition compared to late sowing and also reported that the heat tolerant cultivars required higher number of days for attaining different phenological stages than the heat sensitive cultivars.

\section{Physiological traits}

\section{Flag leaf chlorophyll content}

Flag leaf chl content at 8 days after anthesis (DAA) was not significantly influenced by the interaction effect of wheat varieties and temperature regimes but flag leaf chl content at 24 days after anthesis was significantly influenced (Table 2). Due to heat stress, all the wheat varieties showed lower flag leaf chl content (0.97-1.28 mg chl g-1 FW) compared to control (1.29-1.49

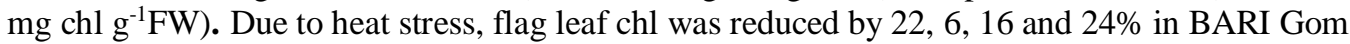
25, BARI Gom 26, BARI Gom 28 and in Sourav.

In the present study flag leaf chl content was reduced in all wheat varieties at 24 days after anthesis. Dhyani et al. (2013) and Almeselmani and Deshmukh (2012) also found that chl content was reduced in wheat due to heat stress. Possible reasons of reduction in chl content due to high temperature stress may be increased activity of peroxidase (Jiang et al., 2007), increase in chlorophyll breakdown (Thomas et al., 1980) and reduction in chl biosynthesis. The present showed that heat tolerant cultivars retain higher amount of chl. 
Table 2. Effect of late planting heat stress on different physiological traits of four wheat varieties

\begin{tabular}{|c|c|c|c|c|c|c|c|c|c|c|c|c|c|}
\hline \multirow[b]{3}{*}{ Wheat varieties } & \multirow[b]{3}{*}{$\begin{array}{l}\text { Temperature } \\
\text { regimes }\end{array}$} & \multicolumn{4}{|c|}{ Flag leaf chl content } & \multicolumn{4}{|c|}{ Proline content } & \multicolumn{4}{|c|}{ CTD } \\
\hline & & \multicolumn{2}{|c|}{ At 8 DAA } & \multicolumn{2}{|c|}{ At 24 DAA } & \multicolumn{2}{|c|}{ Flag leaf } & \multicolumn{2}{|c|}{ Kernel } & \multicolumn{2}{|c|}{ At 8 DAA } & \multicolumn{2}{|c|}{ At 24 DAA } \\
\hline & & $\begin{array}{c}\mathrm{mg} \\
\mathrm{g}^{-1} \mathrm{FW}\end{array}$ & $\begin{array}{c}\text { \% change } \\
\text { over } \\
\text { control }\end{array}$ & $\begin{array}{c}\mathrm{mg} \\
\mathrm{g}^{-1} \mathrm{FW}\end{array}$ & $\begin{array}{c}\% \text { change } \\
\text { over } \\
\text { control }\end{array}$ & $\begin{array}{l}\mu \mu \mathrm{mol} \\
\mathrm{g}^{-1} \mathrm{FW}\end{array}$ & $\begin{array}{c}\% \text { change } \\
\text { over } \\
\text { control }\end{array}$ & $\begin{array}{l}\mu \mu \mathrm{mol} \\
\mathrm{g}^{-1} \mathrm{FW}\end{array}$ & $\begin{array}{c}\text { \% change } \\
\text { over } \\
\text { control }\end{array}$ & ${ }^{\circ} \mathrm{C}$ & $\begin{array}{c}\% \text { change } \\
\text { over } \\
\text { control }\end{array}$ & ${ }^{\circ} \mathrm{C}$ & $\begin{array}{c}\text { \% change } \\
\text { over } \\
\text { control }\end{array}$ \\
\hline \multirow{3}{*}{ BARI Gom 25} & Control & 1.62 & - & $1.49 \mathrm{a}$ & - & $8.10 \mathrm{~b}$ & - & $7.33 \mathrm{~b}$ & - & 4.17 & - & $3.72 \mathrm{a}$ & - \\
\hline & Heat stress & 1.65 & 2 & $1.15 \mathrm{c}$ & -22 & $10.46 \mathrm{a}$ & 29 & $11.05 \mathrm{a}$ & 50 & 2.75 & -34 & $1.58 \mathrm{~b}$ & -57 \\
\hline & Control & 1.78 & - & $1.37 \mathrm{ab}$ & - & $6.75 \mathrm{bc}$ & - & $6.75 \mathrm{~b}$ & - & 4.20 & - & $3.93 \mathrm{a}$ & - \\
\hline \multirow[t]{2}{*}{ BARI Gom 26} & Heat stress & 1.54 & -13 & $1.28 \mathrm{bc}$ & -6 & $8.07 \mathrm{~b}$ & 19 & $10.51 \mathrm{a}$ & 55 & 2.74 & -34 & $1.78 \mathrm{~b}$ & -54 \\
\hline & Control & 1.78 & - & $1.41 \mathrm{ab}$ & - & $7.81 \mathrm{~b}$ & - & $6.25 \mathrm{~b}$ & - & 4.47 & - & $3.93 \mathrm{a}$ & - \\
\hline \multirow[t]{2}{*}{ BARI Gom 28} & Heat stress & 1.75 & -2 & $1.18 \mathrm{c}$ & -16 & $11.34 \mathrm{a}$ & 45 & $10.76 \mathrm{a}$ & 72 & 2.72 & -39 & $1.58 \mathrm{~b}$ & -59 \\
\hline & Control & 1.67 & - & $1.29 \mathrm{bc}$ & - & $5.62 \mathrm{c}$ & - & $6.82 \mathrm{~b}$ & - & 4.37 & - & $3.90 \mathrm{a}$ & - \\
\hline Sourav & Heat stress & 1.78 & 6 & $0.97 \mathrm{~d}$ & -24 & $5.37 \mathrm{c}$ & -4 & $6.65 \mathrm{~b}$ & -2 & 2.75 & -37 & $1.05 \mathrm{c}$ & -73 \\
\hline \multicolumn{2}{|c|}{ Level of significance } & $\mathrm{NS}$ & & $* *$ & & $* *$ & & $* *$ & & NS & & $*$ & \\
\hline $\mathrm{CV}(\%)$ & & 11.34 & & 4.45 & & 8.60 & & 12.41 & & 5.65 & & 8.16 & \\
\hline
\end{tabular}

$\mathrm{CTD}=$ Canopy Temperature Depression, DAA $=$ Days after Anthesis

In a column, values followed by similar letter(s) did not differ significantly by DMRT at $\mathrm{P} \leq 0.05$

Asterisk represents level of significance 


\section{Flag leaf and kernel proline content}

Wheat varieties and temperature regimes interacted significantly to influence flag leaf and kernel Pro content at 16 days after anthesis (Table 2). On November 30 sowing, BARI Gom 25 contained the highest amount of Pro in flag leaf $\left(8.10 \mu\right.$ mole $\left.\mathrm{g}^{-1} \mathrm{FW}\right)$ followed by BARI Gom $28\left(7.81 \mu\right.$ mole $\left.\mathrm{g}^{-1} \mathrm{FW}\right)$ and BARI Gom $26\left(6.75 \mu \mathrm{mole}^{-1} \mathrm{FW}\right)$ while Sourav contained the lowest amount of Pro in flag leaf $\left(5.62 \mu\right.$ mole $\left.^{-1} \mathrm{FW}\right)$. Under late planting heat stress condition, flag leaf Pro was increased by 29,19, 45 in BARI Gom 25, BARI Gom 26 and BARI Gom 28 whereas the flag leaf Pro was reduced by $4.45 \%$ in Sourav compared to control (November 30 sowing). Under control, BARI Gom 25 contained the highest amount of Pro in kernel (7.33 $\mu$ mole $\left.\mathrm{g}^{-1} \mathrm{FW}\right)$ which was followed by Sourav $\left(6.82 \mu\right.$ mole $\left.\mathrm{g}^{-1} \mathrm{FW}\right)$ and BARI Gom 26 (6.75 $\mu$ mole $\left.\mathrm{g}^{-1} \mathrm{FW}\right)$ while BARI Gom 28 contained the lowest amount of Pro in kernel $(6.25 \mu$ mole $\left.\mathrm{g}^{-1} \mathrm{FW}\right)$. Under late planting heat stress condition, kernel Pro was increased by $50 \%$ in BARI Gom 25, 55\% in BARI Gom 26 and $72 \%$ in BARI Gom 28 whereas the kernel Pro was reduced by $2 \%$ in Sourav compared to control (November 30 sowing). Increased Pro synthesis in heat stressed environment may be due to loss of feedback regulation in Pro biosynthetic pathway (Boggess and Stewart 1980).

\section{Canopy temperature depression (CTD)}

Canopy temperature depression at 8 days after anthesis was not influenced significantly by the interaction effect of wheat varieties and temperature regimes but at 24 days after anthesis was influenced significantly (Table 2). At 8 days after anthesis, all the wheat varieties maintained higher canopy temperature depression $\left(4.17\right.$ to $\left.4.47^{\circ} \mathrm{C}\right)$ on November 30 sowing (Control) compared to heat stress condition $\left(2.72\right.$ to $\left.2.75^{\circ} \mathrm{C}\right)$ i.e. all the wheat varieties maintained cooler canopy on November 30 compared to heat stress condition. At 24 days after anthesis, all the wheat genotypes maintained higher $\mathrm{CTD}\left(3.72\right.$ to $\left.3.93^{\circ} \mathrm{C}\right)$ under control compared to that $(1.05$ to $1.78^{\circ} \mathrm{C}$ ) under heat stress condition. CTD was reduced by $57 \%$ in BARI Gom $25,54 \%$ in BARI Gom 26, 59\% in BARI Gom 28 and $73 \%$ in Sourav. In the present study, it was observed that wheat variety BARI Gom 25, BARI Gom 26 and BARI Gom 28 recorded higher CTD under late planting heat stress condition than Sourav. That indicated that three varieties had greater ability to maintain canopy cooler than Sourav. This performance in CTD of different cultivars was reflected to their yield performance.

\section{Spike dry matter accumulation}

A typical sigmoid pattern of dry matter accumulation in spike were found in all wheat varieties both under optimum sowing and late plating heat stress condition (Fig. 2). Under control condition, the spike dry weight was observed to be increased up to $2.38 \mathrm{~g}$ at 40 DAA in BARI Gom 25, $2.77 \mathrm{~g}$ at 40 DAA in BARI Gom 26, $2.55 \mathrm{~g}$ at 36 DAA in BARI Gom 28 and $2.65 \mathrm{~g}$ at 40 DAA in Sourav and decline thereafter slowly. Under heat stress condition, maximum dry matter accumulation in spike was reduced in all wheat varieties and days required to attain maximum dry weight were reduced in all genotypes except BARI Gom 25. The reduction in maximum spike dry weight was $5.46 \%$ in BARI Gom $25,5.56 \%$ in BARI Gom 26, $5.10 \%$ in BARI Gom 28 and $13.96 \%$ in Sourav. Number of days required to attain maximum spike dry weight which indicates grain growth duration were reduced 8 days in BARI Gom 26, 4 days in BARI Gom 28 and 12 days in Sourav whereas no reduction was found in BARI Gom 25 (Fig. 2 and 3). The declining tendency in spike dry weight after attaining the peak could be due to respiratory loss of kernel after physiological maturity. Hasan and Ahmed (2005) and Roy et al. (2013) also found post anthesis heat stress resulted in reduced dry matter accumulation at peak and reduced grain filling period but reductions were lower in heat tolerant genotypes than those in sensitive wheat genotypes. 

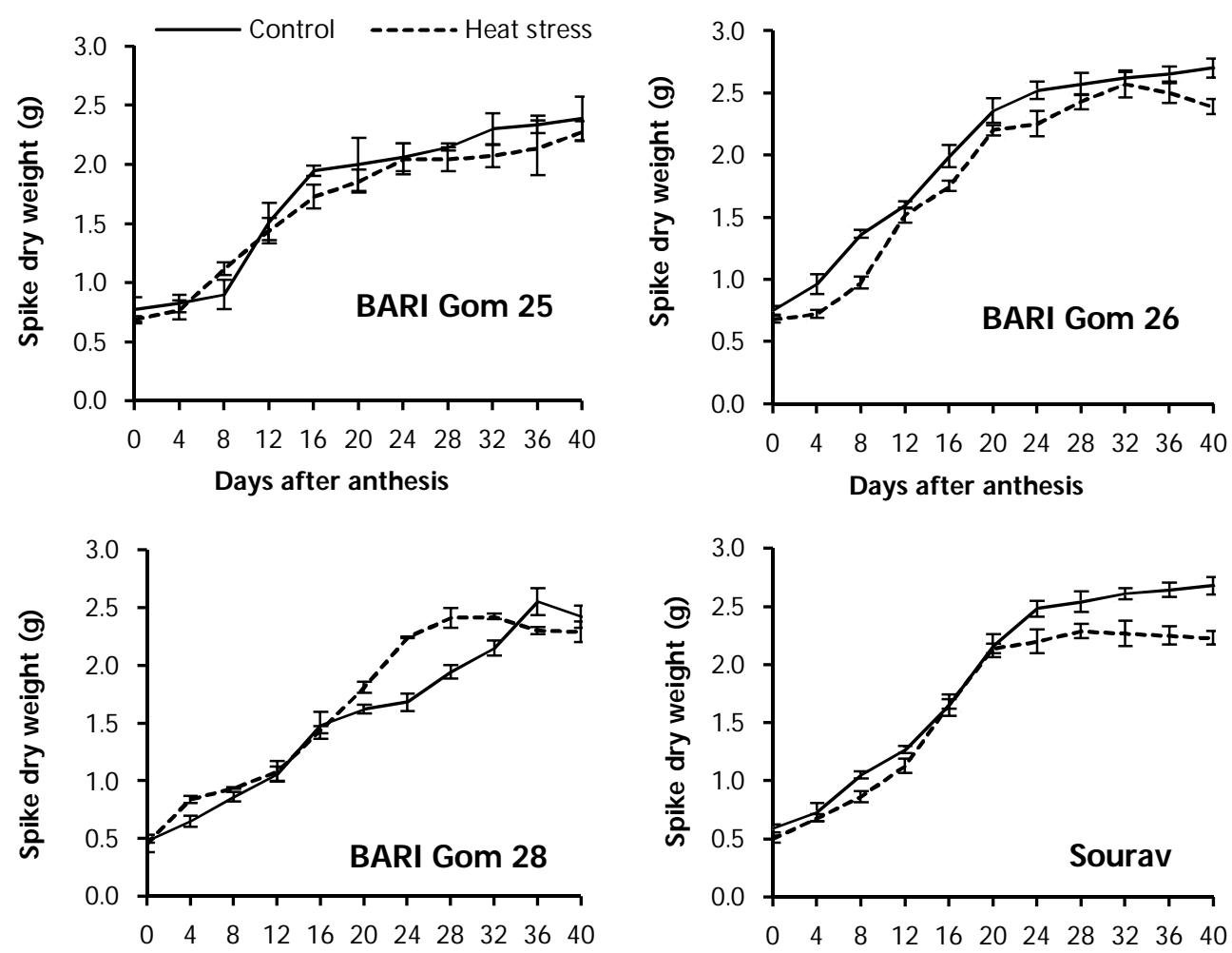

Days after anthesis

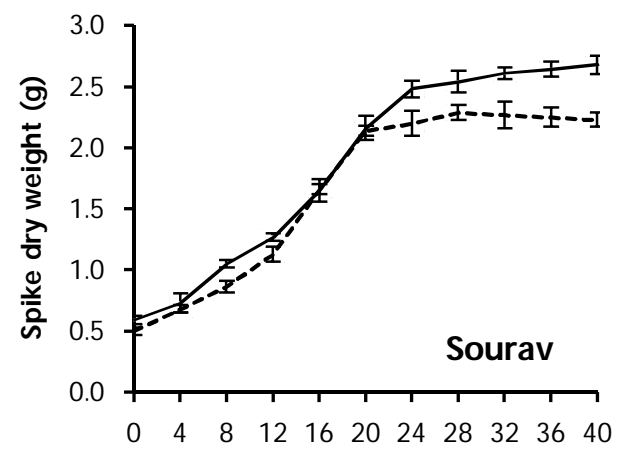

Days after anthesis

Fig. 2. Spike dry matter accumulation in different wheat varieties at different days after anthesis as influenced by late planting heat stress.

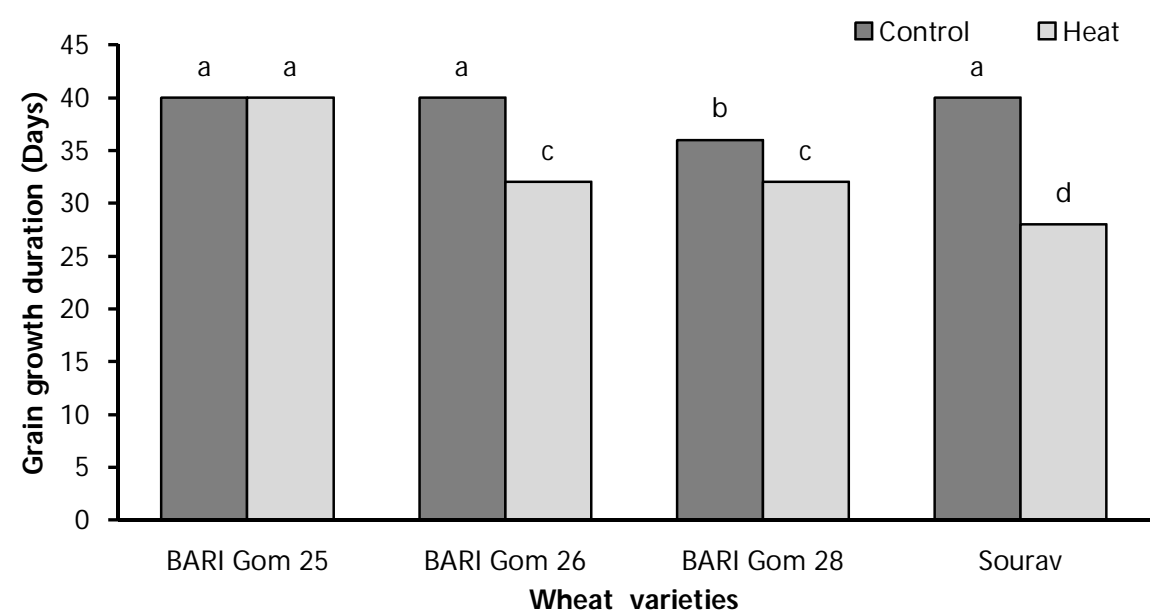

Fig. 3. Effect of late planting heat stress on grain growth duration (days) of different wheat varieties.

Grain dry weight spike ${ }^{-1}$

Grain dry weight spike $^{-1}$ was influenced significantly by the interaction effect of wheat varieties and temperature regimes (Fig. 4). On November 30 sowing, BARI Gom 28 and Sourav 
provided the highest grain dry weight spike ${ }^{-1}$ which was followed by BARI Gom 26 whereas BARI Gom 25 provided the lowest grain dry weight spike ${ }^{-1}$. Due to late planting heat stress, grain dry weight spike ${ }^{-1}$ was reduced in al wheat varieties but the degree of reduction in grain dry weight spike ${ }^{-1}$ was different in different varieties. Grain dry weight spike $^{-1}$ was reduced by $1.74 \%$ in BARI Gom 25, 7.50\% in BARI Gom 26, 9.09\% in BARI Gom 28 and $15.31 \%$ in Sourav due to heat stress compared to control (November 30 sowing).

Hasan and Ahmed (2005) and Roy et al. (2013) also found post anthesis heat stress resulted in reduced grain dry weight spike ${ }^{-1}$ but reductions were lower in heat tolerant genotypes than those in sensitive wheat genotypes. Reduction in grain dry weight spike ${ }^{-1}$ in different magnitude in different wheat genotypes under heat stress might be due to variation in grain growth rate (Hasan and Ahmed, 2005 and Hasan 2009), grain growth duration (Hasan and Ahmed, 2005 and Hasan, 2009) and stem reserve utilization (Roy et al., 2013).

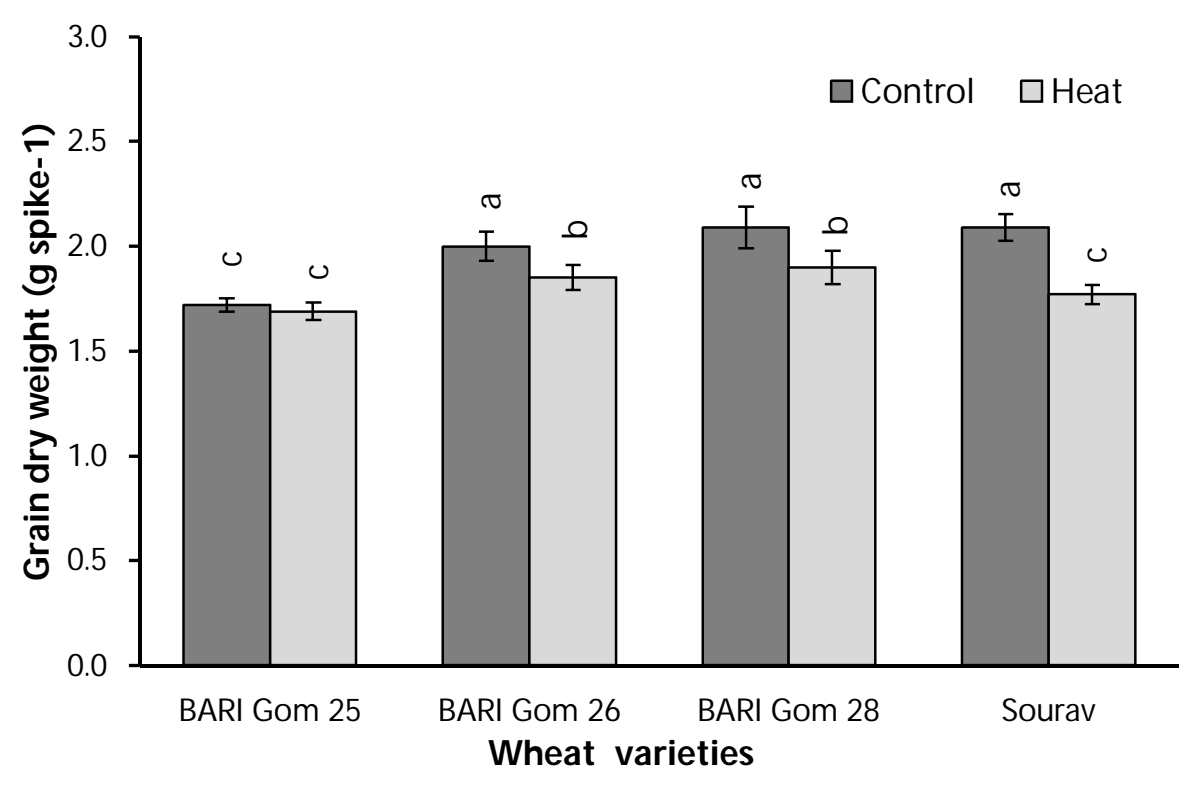

Fig. 4. Effect of late planting heat stress on grain dry weight spike ${ }^{-1}$ of different wheat varieties.

\section{Agronomic traits}

\section{Plant height and spike length at harvest}

Plant height and spike length at harvest were not influenced significantly by the combined effect of wheat varieties and temperature regimes but all the wheat varieties provided shorter plant and spike under optimum sowing compared to late planting heat stress condition except spike length in BARI Gom 26 (Table 3).Due to late planting heat stress, the development of plant organs, photosynthesis rate and transfer of assimilate from source (Sial et al., 2005, Hasan, 2009) were remarkably affected, which was reflected by overall shortening of plant height.

Number of spikes $\mathbf{m}^{-2}$

The combined effect of wheat varieties and temperature regimes on number of spikes $\mathrm{m}^{-2}$ was significant (Table 3). On November sowing (control), the highest number of spikes per $\mathrm{m}^{-2}$ was observed in BARI Gom 28 (351) which was followed by Sourav (308) and BARI Gom 26 (297) whereas, the lowest number of spikes $\mathrm{m}^{-2}$ was observed in BARI Gom 25 (295). Due to the effect of heat stress number of spikes $\mathrm{m}^{2}$ was reduced in all wheat varieties. But the degree of reduction was different in different varieties. Spikes $\mathrm{m}^{-2}$ was reduced by $2 \%$ in BARI Gom 25 , $3 \%$ in BARI Gom 26, $1 \%$ in BARI Gom 28 and $20 \%$ in Sourav due to heat stress compared to 
control (November 30 sowing). Sial et al. (2005), Roy et al. (2013) and Hasan et al. (2007) also found reduced number of ears $\mathrm{m}^{-2}$ in heat stressed environment.

\section{Number of grains spike ${ }^{-1}$}

Number of grains spike ${ }^{-1}$ was significantly influenced by the combined effect of wheat varieties and temperature regimes (Table 3). On November sowing (control), the highest number of grains spike $^{-1}$ was observed in BARI Gom 26 (53) which was followed by BARI Gom 28 (50) and Sourav (49) and whereas the lowest number grains spike ${ }^{-1}$ was observed in BARI Gom 25 (38). Due to the effect of heat stress number of grains spike ${ }^{-1}$ was reduced in different magnitude in different varieties. The reduction was $13 \%$ in BARI Gom $25,1 \%$ in BARI Gom 26, 6\% in BARI Gom 28 and $18 \%$ in Sourav. Significant variation among different wheat genotypes in the reduction in number of grain ear $^{-1}$ under heat stress was found by Hasan et al. (2007), Sial et al. (2005) and Radhika and Thind (2014).

\section{0-grain weight}

The combined effect of wheat varieties and temperature regimes on thousand grain weight was found significant (Table 3). On November sowing (control), the maximum thousand grain weight was recorded in BARI Gom $25(50.93 \mathrm{~g})$ which was followed by BARI Gom 28 (43.80 g) and BARI Gom 26 (42.97) whereas the lowest in Sourav (40.70 g). Due to late planting heat stress thousand grain weights was reduced in all wheat varieties except in BARI Gom 26 but the degree of reduction was different in different varieties. Thousand grain weights were reduced by $4 \%$ in BARI Gom 25, $2 \%$ in BARI Gom 28 and $9 \%$ in Sourav. On the other hand thousand grain weigh was increased somewhat $(0.09 \%)$ due to heat stress in BARI Gom 26. Significant variation in reduction in grain size under heat stress among different wheat genotypes was also observed by Sial et al. (2005), Dhyani et al. (2013) and Hasan and Ahmed (2005). Greater grain size in heat tolerant genotypes due to longer duration of rapid grain growth rate (Hasan and Ahmed 2005). 
Table 3. Effect of late planting heat stress on agronomical traits of wheat varieties

\begin{tabular}{|c|c|c|c|c|c|c|c|c|c|c|c|c|c|c|c|}
\hline \multirow[b]{2}{*}{$\begin{array}{l}\text { Wheat } \\
\text { varieties }\end{array}$} & \multirow[b]{2}{*}{$\begin{array}{l}\text { Tempera- } \\
\text { ture } \\
\text { regimes }\end{array}$} & \multicolumn{2}{|c|}{ Plant height } & \multicolumn{2}{|c|}{ Spike length } & \multicolumn{2}{|c|}{ Spike $\mathrm{m}^{-2}$} & \multicolumn{2}{|c|}{ Grains spike $^{-1}$} & \multicolumn{2}{|c|}{1000 -grain weight } & \multicolumn{2}{|c|}{ Grain yield } & \multicolumn{2}{|c|}{$\begin{array}{c}\text { Above ground } \\
\text { biological yield }\end{array}$} \\
\hline & & $\mathrm{cm}$ & $\begin{array}{c}\% \\
\text { change } \\
\text { over } \\
\text { control } \\
\end{array}$ & $\mathrm{cm}$ & $\begin{array}{c}\% \\
\text { change } \\
\text { over } \\
\text { control } \\
\end{array}$ & number & $\begin{array}{c}\% \\
\text { change } \\
\text { over } \\
\text { control } \\
\end{array}$ & number & $\begin{array}{c}\% \text { change } \\
\text { over } \\
\text { control }\end{array}$ & $\mathrm{g}$ & $\begin{array}{c}\text { \% change } \\
\text { over } \\
\text { control }\end{array}$ & tha $^{-1}$ & $\begin{array}{c}\% \text { change } \\
\text { over } \\
\text { control }\end{array}$ & tha $^{-1}$ & $\begin{array}{c}\% \\
\text { change } \\
\text { over } \\
\text { control }\end{array}$ \\
\hline \multirow{2}{*}{$\begin{array}{l}\text { BARI } \\
\text { Gom } 25\end{array}$} & Control & 107.9 & - & 11.4 & - & $295 \mathrm{~b}$ & - & $38 \mathrm{~d}$ & - & $50.93 \mathrm{a}$ & - & $3.12 \mathrm{a}$ & - & $9.32 \mathrm{a}$ & - \\
\hline & Heat stress & 97.0 & -10 & 10.6 & -7 & $288 \mathrm{~b}$ & -2 & $33 \mathrm{e}$ & -13 & $48.83 \mathrm{~b}$ & -4 & $2.65 \mathrm{~b}$ & -15 & $6.74 \mathrm{bc}$ & -27 \\
\hline \multirow{2}{*}{$\begin{array}{l}\text { BARI } \\
\text { Gom } 26\end{array}$} & Control & 102.8 & - & 10.1 & - & $297 \mathrm{~b}$ & - & $53 \mathrm{a}$ & - & $42.97 \mathrm{c}$ & - & $3.49 \mathrm{a}$ & - & $9.23 \mathrm{a}$ & - \\
\hline & Heat stress & 96.0 & -6 & 10.4 & 3 & $288 \mathrm{~b}$ & -3 & $52 \mathrm{ab}$ & -2 & $42.93 \mathrm{c}$ & 0.09 & $2.71 \mathrm{~b}$ & -22 & $6.75 \mathrm{bc}$ & -26 \\
\hline \multirow{2}{*}{$\begin{array}{l}\text { BARI } \\
\text { Gom } 28\end{array}$} & Control & 103.0 & - & 10.7 & - & $351 \mathrm{a}$ & - & $50 \mathrm{ac}$ & - & $43.80 \mathrm{c}$ & - & $3.26 \mathrm{a}$ & - & $8.94 \mathrm{a}$ & - \\
\hline & Heat stress & 97.1 & -5 & 9.2 & -14 & $346 \mathrm{a}$ & -1 & $47 \mathrm{c}$ & -6 & $42.53 \mathrm{~cd}$ & -2 & $2.67 \mathrm{~b}$ & -18 & $7.51 \mathrm{~b}$ & -15 \\
\hline \multirow{4}{*}{ Sourav } & Control & 103.6 & - & 10.9 & - & $308 \mathrm{~b}$ & - & $49 \mathrm{bc}$ & - & $40.70 \mathrm{c}$ & - & $3.47 \mathrm{a}$ & - & $9.53 \mathrm{a}$ & - \\
\hline & Heat stress & 99.9 & -3 & 10.5 & -3 & $246 \mathrm{c}$ & -20 & $40 \mathrm{~d}$ & -18 & $36.77 \mathrm{e}$ & -9 & $2.16 \mathrm{c}$ & -37 & $5.94 \mathrm{c}$ & -37 \\
\hline & $\begin{array}{l}\text { Level of } \\
\text { significance }\end{array}$ & NS & & NS & & $* *$ & & $* *$ & & $* *$ & & $* *$ & & $* *$ & \\
\hline & $\mathrm{CV}(\%)$ & 4.94 & & 2.84 & & 3.22 & & 3.17 & & 1.90 & & 4.84 & & 5.09 & \\
\hline
\end{tabular}

In a column, values followed by similar letter(s) did not differ significantly by DMRT at $\mathrm{P} \leq 5 \%$

Asterisk represents level of significance 


\title{
Grain yield
}

The combined effect of wheat varieties and temperature regimes on grain yield was found significant. (Table 3). On November sowing (control), the maximum grain yield was recorded in BARI Gom 26 (3.49 $\left.\mathrm{t} \mathrm{ha}^{-1}\right)$ which was followed by Sourav (3.47 $\left.\mathrm{t} \mathrm{ha}^{-1}\right)$ and BARI Gom 28 (3.26 $\left.\mathrm{t} \mathrm{ha}^{-1}\right)$ whereas the lowest grain yield was found in BARI Gom $25\left(3.12 \mathrm{t} \mathrm{ha}^{-1}\right)$. Due to late planting, heat stress grain yield was reduced in all wheat varieties but the degree of reduction was different in different varieties. Grain yield was reduced by $15 \%$ in BARI Gom 25, $22 \%$ in BARI Gom 26, $18 \%$ in BARI Gom 26 and 37\% in Sourav. Significant variation in reduction in grain yield in different wheat genotypes due to heat stress was also found by Baloch et al. (2012), Khan and Kabir (2014), Laghari et al. (2012), Dhyani et al. (2013), Radhika and Thind (2014), Hasan et al. (2007) and Roy et al. (2013). They found that better performance of all the yield parameters such as number of spike $\mathrm{m}^{-2}$, number of grains spike ${ }^{-1}$, grain weight spike $^{-1}$ and grain size had contribution to better grain yield of heat tolerant wheat genotypes.

\begin{abstract}
Above ground biological yield
Above ground biological yield was influenced significantly by the combined effect of wheat varieties and temperature regimes (Table 3). On November sowing (control), the highest above ground biological yield was recorded in Sourav $\left(9.53 \mathrm{tha}^{-1}\right)$ which was followed by BARI Gom $25\left(9.32 \mathrm{t} \mathrm{ha}^{-1}\right)$ and BARI Gom $26\left(9.23 \mathrm{t} \mathrm{ha}^{-1}\right)$ whereas the lowest above ground biological yield was found in BARI Gom $28\left(8.94 \mathrm{t} \mathrm{ha}^{-1}\right)$. Due to late planting heat stress, above ground biological yield was reduced in all wheat varieties but the degree of reduction was different in different varieties. The reduction was $27 \%$ in BARI Gom $25,26 \%$ in BARI Gom $26,15 \%$ in BARI Gom 28 and 37\% in Sourav. The reduced above ground biological yield in wheat under heat stress was due to the reduced grain and straw yield. Khan and Kabir (2014), Hasan and Ahmed (2005) and Roy et al. (2013) also reported reduced biological yield under high temperature.
\end{abstract}

\section{Correlation analysis between relative performances of various parameters}

Correlation analysis between relative performances of various parameters studied in this investigation is presented in Table 4. Relative grain yield maintained a significant positive correlation with relative flag leaf chl content at 24 DAA $\left(0.43^{*}\right)$, relative flag leaf Pro content at 16 DAA $\left(0.89^{* *}\right)$, relative kernel Pro content at 16 DAA $(0.91 * *)$, relative canopy temperature depression at 24 DAA $\left(0.88^{* *}\right)$, relative spikes $\mathrm{m}^{-2}\left(0.97^{* *}\right)$, relative grains $\operatorname{spike}^{-1}\left(0.57^{* *}\right)$, relative thousand grain weight $(0.77 * *)$, relative grain dry weight $\operatorname{spike}^{-1}\left(0.90^{* *}\right)$ and above ground biological yield $(0.77 * *)$. Nagrajan and Rane (2002) reported a significant correlation between grain weight spike $^{-1}$ and CTD in general. Hasan and Ahmed (2005) was found significant positive correlation between Pro level and grain yield of wheat under heat stress environment. 
Table 4. Relationship among the relative performances of physiological traits, grain yield and straw yield of different wheat varieties

\begin{tabular}{|c|c|c|c|c|c|c|c|c|c|c|}
\hline & $\begin{array}{c}\text { Relative } \\
\text { flag leaf } \\
\text { chl content } \\
\text { at } \\
24 \text { DAA }\end{array}$ & $\begin{array}{l}\text { Relative } \\
\text { flag leaf } \\
\text { Pro } \\
\text { content at } \\
16 \text { DAA }\end{array}$ & $\begin{array}{l}\text { Relative } \\
\text { kernel Pro } \\
\text { content at } \\
16 \text { DAA }\end{array}$ & $\begin{array}{c}\text { Relative } \\
\text { canopy } \\
\text { temperature } \\
\text { depression } \\
\text { at24 DAA }\end{array}$ & $\begin{array}{l}\text { Relative } \\
\text { spikes } \\
\mathrm{m}^{-2}\end{array}$ & $\begin{array}{l}\text { Relative } \\
\text { grains } \\
\text { spike }^{-1}\end{array}$ & $\begin{array}{l}\text { Relative } \\
\text { thousand } \\
\text { grain } \\
\text { weight }\end{array}$ & $\begin{array}{l}\text { Relative } \\
\text { grain dry } \\
\text { weight } \\
\text { spike }^{-1}\end{array}$ & $\begin{array}{l}\text { Relative } \\
\text { grain } \\
\text { yield }\end{array}$ & $\begin{array}{l}\text { Relative } \\
\text { above } \\
\text { ground } \\
\text { biological } \\
\text { yield } \\
\end{array}$ \\
\hline \multicolumn{11}{|l|}{$\begin{array}{l}\text { Relative flag leaf chl } \\
\text { content at } 24 \text { DAA }\end{array}$} \\
\hline $\begin{array}{l}\text { Relative flag leaf Pro } \\
\text { content at } 16 \text { DAA }\end{array}$ & $0.57 * *$ & & & & & & & & & \\
\hline $\begin{array}{l}\text { Relative kernel Pro content } \\
\text { at } 16 \mathrm{DAA}\end{array}$ & $0.75^{* *}$ & $0.95 * *$ & & & & & & & & \\
\hline $\begin{array}{l}\text { Relative canopy } \\
\text { temperature depression at } \\
24 \text { DAA }\end{array}$ & $0.67 * *$ & $0.71 * *$ & $0.88 * *$ & & & & & & & \\
\hline Relative spikes $\mathrm{m}^{-2}$ & $0.63 * *$ & $0.60 * *$ & $0.97 * *$ & $0.94 * *$ & & & & & & \\
\hline Relative grains spike ${ }^{-1}$ & $0.97 * *$ & $0.60 * *$ & $0.81 * *$ & $0.82 * *$ & $0.75 * *$ & & & & & \\
\hline $\begin{array}{l}\text { Relative thousand } \\
\text { grain weight }\end{array}$ & $0.74 * *$ & $0.67 * *$ & $0.87 * *$ & $0.97 * *$ & $0.88 * *$ & $0.94 * *$ & & & & \\
\hline $\begin{array}{l}\text { Relative grain dry weight } \\
\text { spike }^{-1}\end{array}$ & $0.15^{\mathrm{NS}}$ & $0.60 * *$ & $0.67 * *$ & $0.83 * *$ & $0.81 * *$ & $0.37 *$ & $0.66 * *$ & & & \\
\hline Relative grain yield & $0.43^{*}$ & $0.89 * *$ & $0.91 * *$ & $0.88 * *$ & $0.97 * *$ & $0.57 * *$ & $0.77 * *$ & $0.90 * *$ & & \\
\hline $\begin{array}{l}\text { Relative above ground } \\
\text { biological yield }\end{array}$ & $0.73 * *$ & $0.96 * *$ & $0.93 * *$ & $0.65 * *$ & $0.84 * *$ & $0.70 * *$ & $0.68 * *$ & $0.41^{*}$ & $0.77 * *$ & \\
\hline
\end{tabular}




\section{Stress susceptible index (SSI)}

Fig. 5 shows stress susceptibility index of different wheat varieties based on grain yield. Wheat var. BARI Gom 25 showed the lowest heat stress susceptibility index that was followed by BARI Gom 28 and BARI Gom 26. Sourav showed the highest heat stress susceptibility index. These stress susceptibility index values indicated that BARI Gom 25, BARI Gom 26 and BARI Gom 28 were heat tolerant varieties and Sourav was heat susceptible variety.

Fig. 6 shows stress susceptibility index of different wheat varieties based on above ground biological yield. BARI Gom 28 showed the lowest heat stress susceptibility index that was followed by BARI Gom 26 and BARI Gom 25. Sourav showed the highest heat stress susceptibility index. These stress susceptibility index values indicated that BARI Gom 25, BARI Gom 26 and BARI Gom 28 were more tolerant varieties than Sourav. Hossain et al. (2013), Agrawal et al. (2014), Hasan and Ahmed (2005) and Rasal et al. (2006) found that the heat tolerant genotypes showed lower susceptibility index than the heat sensitive genotype.

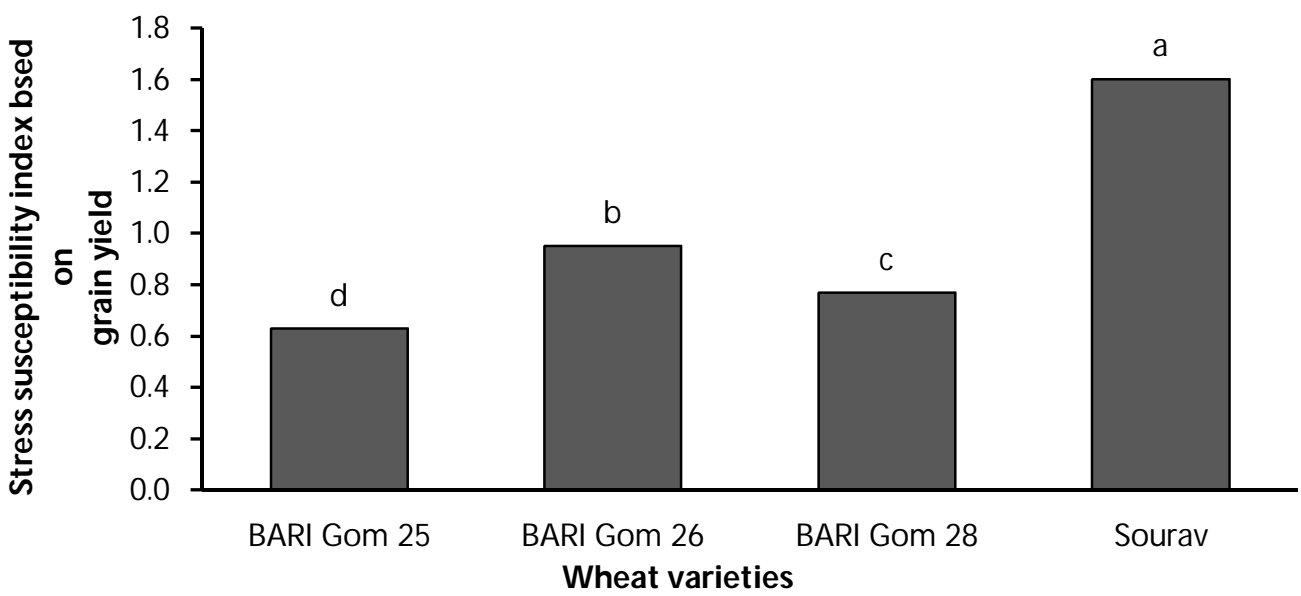

Fig. 5. Stress susceptibility index of different wheat varieties based on grain yield.

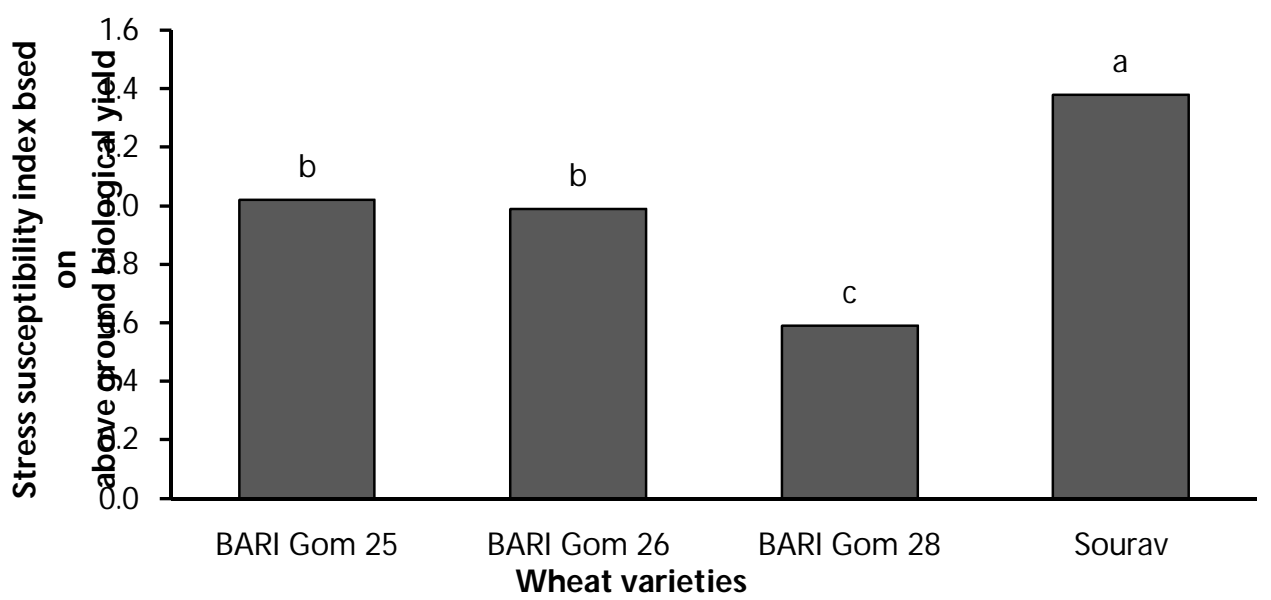

Fig. 6. Stress susceptibility index of different wheat varieties based on above ground biological yield.

\section{Conclusion}


From the overall results it may be concluded that wheat var. BARI Gom 25, BARI Gom 26 and BARI Gom 28 showed greater stability in chl and higher level of Pro in flag leaf and kernel as well as greater ability to keep the canopy cooler compared to Sourav under late planting heat stress condition. Greater spike dry matter accumulation at peak, longer grain growth duration, better yield components such as spikes $\mathrm{m}^{-2}$, grains spike ${ }^{-1}$, grain weight spike ${ }^{-1}$ and 1000 -grain weight under heat stress contributed to better tolerance of BARI Gom 25, BARI Gom 26 and BARI Gom 28. The order of tolerance based on grain yield was BARI Gom $25>$ BARI Gom 28 $>$ BARI Gom $26>$ Sourav and the order of tolerance based on above ground biological yield was BARI Gom $28>$ BARI Gom $26>$ BARI Gom $25>$ Sourav.

\section{References}

Agrawal, A. P., D. Pandey and D. Pandey. 2014. Variation parameters for heat tolerance index of wheat. J. Wheat Res. 6(1):37-40.

Almeselmani, M. and P. S. Deshmukh. 2012. Effect of high temperature stress on physiological and yield parameters of some wheat genotypes recommended for irrigated and rainfed condition. Jordan J. Agri. Sci. 8 (1): 66-77.

Anonymous. 2014. Yearbook of agricultural statistics of Bangladesh, Bangladesh Bureau of Statistics, Ministry of planning, Government of the people's Republic of Bangladesh.

Badaruddin, M., D. A. Sauders, A. B. Siddique, M. A. Hossain, M. O. Ahmed, M. M. Rahman and S. Parveen. 1994. Determining yield constraints for wheat production in Bangaldesh. p. 265271. In D. A. Saunders and G. P. Hettel (eds.) Wheat in heat stressed environments; irrigated, dry areas and rice-wheat farming systems. CIMMYT, Mexico, D. F.

Baloch, M. S., M. A. Nadim, M. Zubair, I. U. Awan, E. A. Khan and S. Ali. 2012. Evaluation of wheat under normal and late sowing conditions. Pak. J. Bot. 44(5): 1727-1732

Bates, L. S. 1973. Rapid determination of free proline for water-stress studies. Plant Soil 39:205-207.

Bogess, S. F. and C. R. Stewart. 1980. The relationship between water stress induced proline accumulation and inhibition of protein synthesis in tobacco leaves. Plant Sci. Lett17:245252.

Dhyani, K., M. W. Ansari, Y. R. Rao, R. S. Verma, A. Shukla and N.Tuteja. 2013. Comparative physiological response of wheat genotypes under terminal heat stress. Plant Signaling \& Behavior 8(6): 1-6.

Hasan, M. A. 2009. Physiology of sustaining wheat yield under late planting heat stressed environment. Ph. D Thesis, Department of Crop Botany, BSMRAU, Gazipur.

Hasan, M. A. and J. U. Ahmed. 2005. Kernel growth physiology of wheat under late planting heat stress. J. Natn. Sci. Foundation Sri Lanka 33(3):193-204.

Hasan, M. A., J. U. Ahmed, M. M. Bahadur, M. M. Haque and S. Sikder. 2007. Effect of late planting stress on membrane thermostability, proline content and heat susceptibility index of different wheat cultivars. J. Natn. Sci. Foundation Sri Lanka 35(2):109-117.

Hossain, A., M. A. Z. Sarker, M. Saifuzzaman, J. A. Teixeira da Silva, M. V. Lozovskaya, M. M. Akhter. 2013. Evaluation of growth, yield, relative performance and heat susceptibility of eight wheat (Triticum aestivum L.) genotypes grown under heat stress. Int. J. Plant Prod.7 (3): 615-636.

Jiang, C., Y. Yin, X. Liu and Z. Wang. 2007. Response of flag leaf lipid per oxidation and protective enzyme activity of wheat cultivars with different heat tolerant to high temperature stress after anthesis. Acta Agron. Sin. 3(1): 143-148.

Keeling, P. L., R. Banisadr, L. Barone, B. P. Wasserman and G. W. Singletary. 1994. Effect of temperature on enzymes in the pathway of starch biosynthesis in developing wheat and maize grain. Aust. J. Plant Physiol. 21: 807-827. 
Khan, A. A. and M. R. Kabir. 2014. Evaluation of spring wheat genotypes (Triticum aestivum L.) for heat stress tolerance using different stress tolerance indices. Cercetari Agronomice in Moldova. 47(4): 49-63.

Laghari, K. A., M. A. Sial and M. A. Arain. 2012. Effect of high temperature stress on grain yield and yield components of wheat (Triticum aestivum L.). Sci. Technol Dev. 31 (2): 83-90.

Nagrajan, S. and J. Rane. 2002. Physiological traits associated with yield performance of spring wheat under late sown conditions. Indian J. Agric. Sci. 72(3): 135-140.

Radhika, and S. K. Thind. 2014. Various agronomic traits as affected by sowing date mediated heat stress conditions. Int. J. Agri. Crop Sci. 7 (2): 76-78.

Rasal, P. N., V. N. Gavhane, D. V. Kusalkar, A. B. Gosavi and G. N. Shirpurkar. 2006. Effect of high temperature stress on heat susceptibility index and thermal requirement of bread wheat genotypes. Res. Crops. 7(3): 811-813.

Renolds, M. P., R. P. Singh, A. Ibrahim, O. A. A. Ageeb, A. Larque- Saavedra and J. S. Quick. 1998. Evaluating physiological traits to complement empirical selection for wheat in warm environments. Euphytica, 100: 84-95.

Reynolds, M. P., M. Balota, M. I. B. Delgado, I. Amani, and R.A. Fischer. 1994. Physiological and morphological traits associated with spring wheat yield under hot, irrigated conditions. Aust. J. Plant Physiol. 21:717-30.

Roy, T. K., M. H. R. Hafiz, M. R. Islam, M. A. Hasan and M. N. Siddiqui. 2013. Late planting heat stress on ear growth physiology of wheat. Int. J. Biol. 3(11): 8-19.

Schonfeld, M. A., R. C. Johnson, B. F. Carver and D. W. Mornhinweg. 1988. Water relations in winter wheat as drought resistance indicator. Crop. Sci. 28: 526-531.

Sial, M. A., M. A. Arain, K. Shamadad, M. H. Naqvi, M. U. Dahot and N. A. Nizamani. 2005. Yield and quality parameters of wheat genotypes as affected by sowing dates and high temperature stress. Pak J. Bot.. 37(3): 575-584.

Sikder, S. 2009. Accumulation heat unit and phenology of wheat cultivars as influenced by late sowing heat stress condition. Agril. Rural Dev. 7(1\&2):57-64.

Sikder, S. and N. K. Paul. 2010. Study of influence of temperature regimes on germination characteristics and seed reserves mobilization in wheat. Afr. J. Plant Sci. 4(10): 401-408.

Thomas, H., J. L. Stoddart and J. F. Potter. 1980. Temperature responses of membrane associated activities from spring and winter oats. Plant Cell Environ. 3: 271-277.

Witham, H., D. F. Blades and R. H. Devin. 1986. Exercise in plant physiology ( $2^{\text {nd }}$ edition), PWS Publishers, Boston, USA, Pp. 128-131.

Zhong-hu, H. and S. Rajaram (1994): Differential responses of bread wheat characters to high temperature. Euphytica. 72: 197-203. 